\title{
OPTIMIZATION OF MANAGEMENT DECISIONS FOR CHOOSING STRATEGY OF ENTERPRISES FIXED ASSETS REPRODUCTION
}

\author{
Aleksandr Birjukov ${ }^{1}$, Evgeniy Dobryshkin ${ }^{2}$, Igor Kravchenko ${ }^{2}$, Maxim Glinskiy ${ }^{2}$ \\ ${ }^{1}$ Department of Technology, Organization and Construction Economics, \\ Military Academy of Logistics named Army General A.V. Chrulev, St. Petersburg, Russia; \\ ${ }^{2}$ Department of Technical Service of Machinery and Equipment, Russian State Agrarian University- \\ Moscow Agricultural Academy named after K.A. Timiryazev, Moscow, Russia \\ aleks_bir@mail.ru, edobryshkin@mail.ru,kravchenko-in71@yandex.ru, maximagl@yandex.ru
}

\begin{abstract}
In most industrialized countries fixed assets dominate in the structure of national wealth. As elements of fixed assets, the authors of this article consider industrial and non-industrial buildings as part of enterprises of the agroindustrial complex. The study of the effectiveness of building restoration shows that the criteria for effective repair and reconstruction of a building are the maximum reduction in physical wear and minimum capital investments. Based on the analysis of defects in building structures found during the determination of the technical condition of buildings of enterprises of the agroindustrial sector, the article formulates the classification of the most frequent defects that reduce the performance properties of fixed assets of enterprises and sets the mathematical dependence of the physical deterioration of fixed assets from the period of their operation correlation regression equation. Based on the carried-out modelling of the intensity of wear, a system for monitoring the technical condition of buildings based on the so-called "controlled operation" of buildings is proposed in order to effectively use depreciation charges to eliminate physical deterioration of buildings. Based on the results of the study of methods for calculating depreciation and regulatory documents governing the respective service life of buildings, a method was developed to optimize the planning of capital investments to eliminate the physical deterioration of the enterprise's buildings as elements of fixed assets. The application of the developed method allows to increase the efficiency of management decision-making by the management of the enterprise, which has an impact on the effectiveness of the finished product output by enterprises of the agroindustrial complex.
\end{abstract}

Keywords: fixed assets, agroindustrial complex, management, restoration, rehabilitation.

\section{Introduction}

Many scientists agree that fixed assets occupy dominant positions in the structure of the national wealth of the Russian Federation, they account for about $70 \%$, while the share of this category has remained almost unchanged over the past 25 years [1].

At the same time, according to information for 2011, Russian federal agencies estimated the level of depreciation of fixed assets in Russia at 45-65 \% [2]. Research across the country showed that at the current stage the increase in the depreciation of fixed assets in all major types of economic activity from 2005 to 2016 was $5.2 \%$ and reached $48.7 \%$, while for some types it exceeded $55 \%$ [3].

As elements of fixed assets, the authors of this article consider industrial and non-industrial buildings as part of the agroindustrial complex (AIC) enterprises in the Russian Federation.

The analysis carried out showed that for certain types of activities the cost of buildings as elements of fixed assets is $45 \%$ of the total value of fixed assets of an enterprise. An analysis of the performance of work by type of economic activity by organizations of various forms of ownership showed that the volume of work performed by organizations of private form of ownership significantly exceeds the amount of work performed by state and municipal enterprises (93\% vs $7 \%$ ). The conducted researches showed that 4122.2 thousand enterprises are organizations of private form of ownership against 311 thousand enterprises of state and municipal forms of ownership.

The study of the reconditioning experience of industrial and non-industrial buildings as elements of fixed assets of enterprises shows that the preservation and renovation of fixed assets is carried out through current or capital repairs, modernization, reconstruction and new construction [4-9]. At the same time, preference is given in favor of new construction in the absence of the economic viability of carrying out repairs and reconstruction with significant levels of the development of physical deterioration of buildings [7;9-12]. However, a number of researchers point to the fact that in Russia not a single reproduction cycle at industrial enterprises ended with the replacement of the worn-out active part of fixed assets at the expense of depreciation funds of enterprises [2] at a time, when the 
calculations of the Institute of Economics of the Russian Academy of Sciences show that amortization is the most effective investment resource.

The study of the effectiveness of building restoration shows that the criteria for effective repair and reconstruction of a building is the maximum reduction in the level of physical deterioration with minimum capital investments [5;7;9;13-15].

The problem of buildings technical condition determines the relevance of the task of developing an effective scientific and methodological decision-making apparatus for choosing a strategy for the reproduction of fixed assets $[7 ; 9 ; 16-19]$. One of the stages of solving this task is to prevent the occurrence of emergency situations, the validity of the choice of the complex of engineering measures to prevent them, which will ensure the proper reproduction rate of fixed assets. Obviously, the control of the technical condition of the building structures should be systematic and allow the assessment of the changes taking place on the basis of quantitative criteria, that is, be based on the procedures for identifying the compliance of the actual strength, rigidity and stability of structural elements with the regulatory requirements $[7 ; 9 ; 16 ; 20-23]$. At the same time, the analysis of a significant amount of statistical material carried out by the authors shows that, as a result of aging and deterioration of existing buildings of enterprises in Russia, there is a progressive increase in the volume of necessary restoration work, and the dynamics of changes in the technical condition of the buildings in question lead to that every year the category of the technical condition of fixed assets in the Russian Federation significantly deteriorates. The deterioration of the technical condition of the buildings of enterprises is explained by insufficient financing, non-observance of standards and operating rules.

In the course of a study of a number of buildings at Russian enterprises [24;25], it was determined that most of the buildings need timely maintenance, major repairs, and in some cases reconstruction. The lack of timely maintenance, the need to make informed management decisions on the reproduction of fixed assets, as well as the long service life of buildings in the enterprise lead to the accumulation of considerable physical deterioration.

Thus, the objective and scope of the current work is to propose the advanced scientific and methodological decision-making apparatus for management and choosing a strategy for the reproduction of fixed assets.

\section{Materials and methods}

Analysis of the technical condition of AIC enterprises fixed assets in Russia showed that at present most of the buildings were commissioned before 1990, and the volume of reproduction of fixed assets through new construction is not significant (Figure 1).

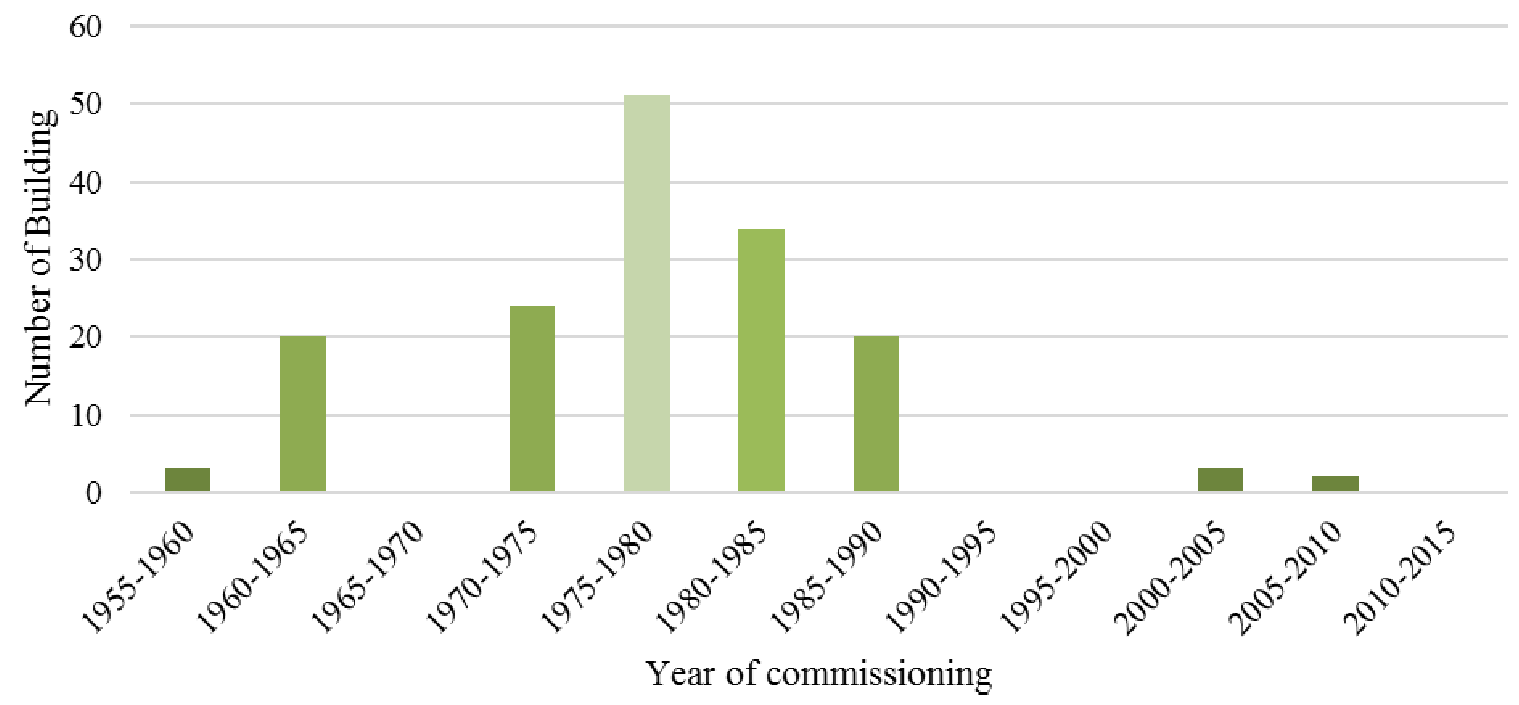

Fig. 1. Distribution of analysed enterprises buildings in Russia by year of construction

Analysis of defects in building structures during the determination of the technical condition of enterprise's buildings in Russia allows us to formulate the following classification of the most common defects that reduce the operational properties of fixed assets of enterprises (Figure 2). 


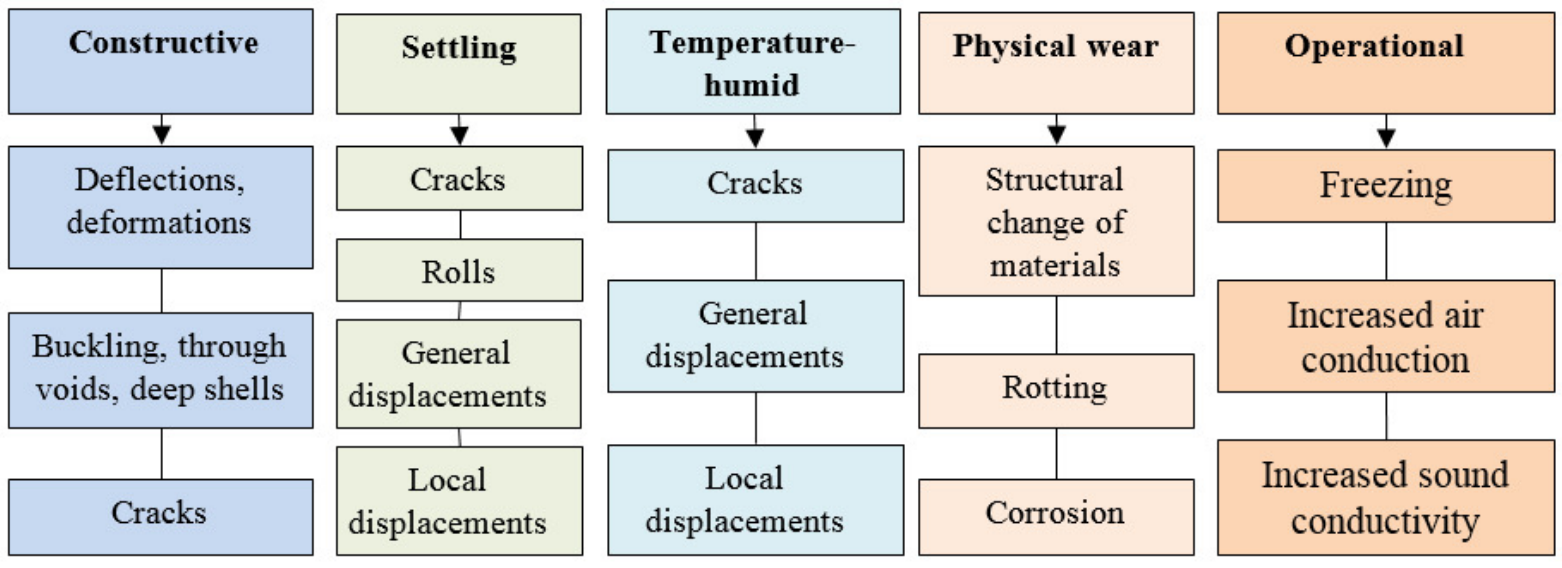

Fig. 2. Fault classification for buildings to be monitored

After analysing the years of AIC enterprise's buildings commissioning on the territory of the Russian Federation (Figure 1), the authors constructed a histogram of the distribution of the average year of construction (Figures 3,4 ) according to the law of normal distribution.

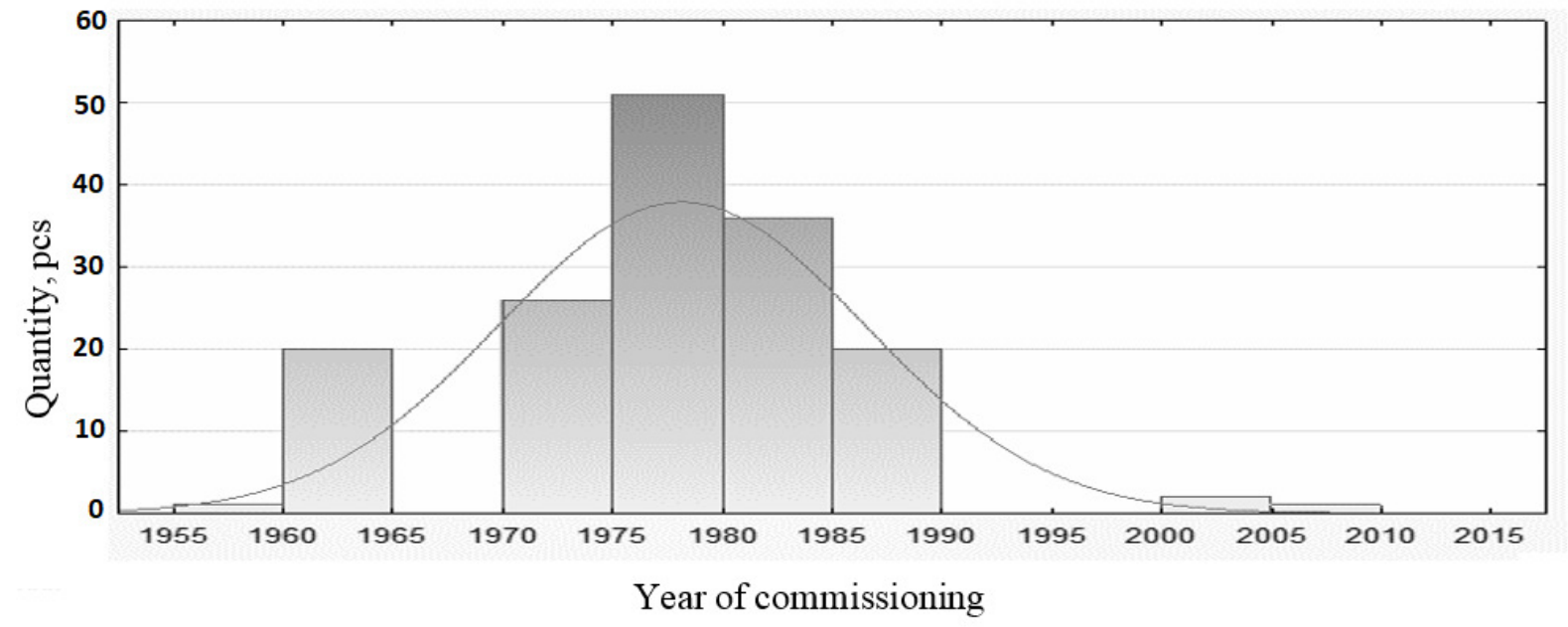

Fig. 3. Histogram of distribution of buildings as elements of fixed assets of enterprises in the Russian Federation by year of construction
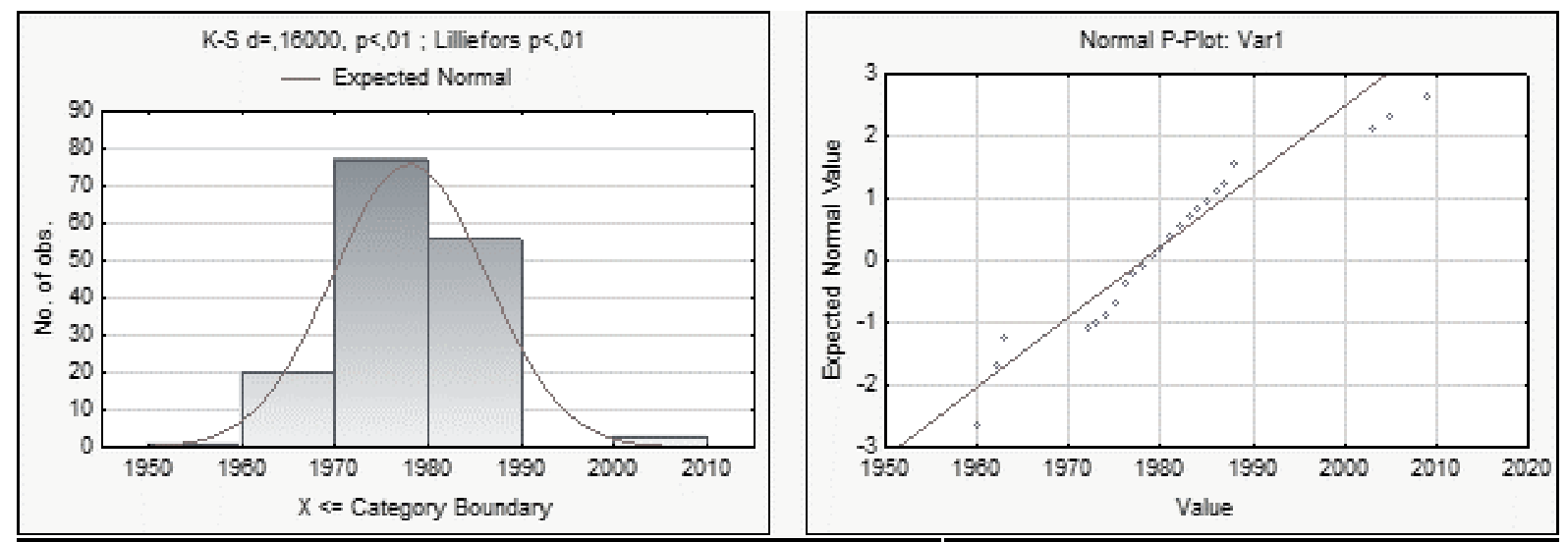

Fig. 4. Histogram presenting distribution of year of construction and its fitting to normal distribution

The analysis of statistical data prepared by the authors during the determination of the enterprise's buildings technical condition in the Russian Federation is presented as a correlation field (Figure 6), in which the average values can be distinguished and set as a function of physical wear. Physical wear 
levels were evaluated by the expert committees as complex deterioration figure mainly based on a visual inspections result.

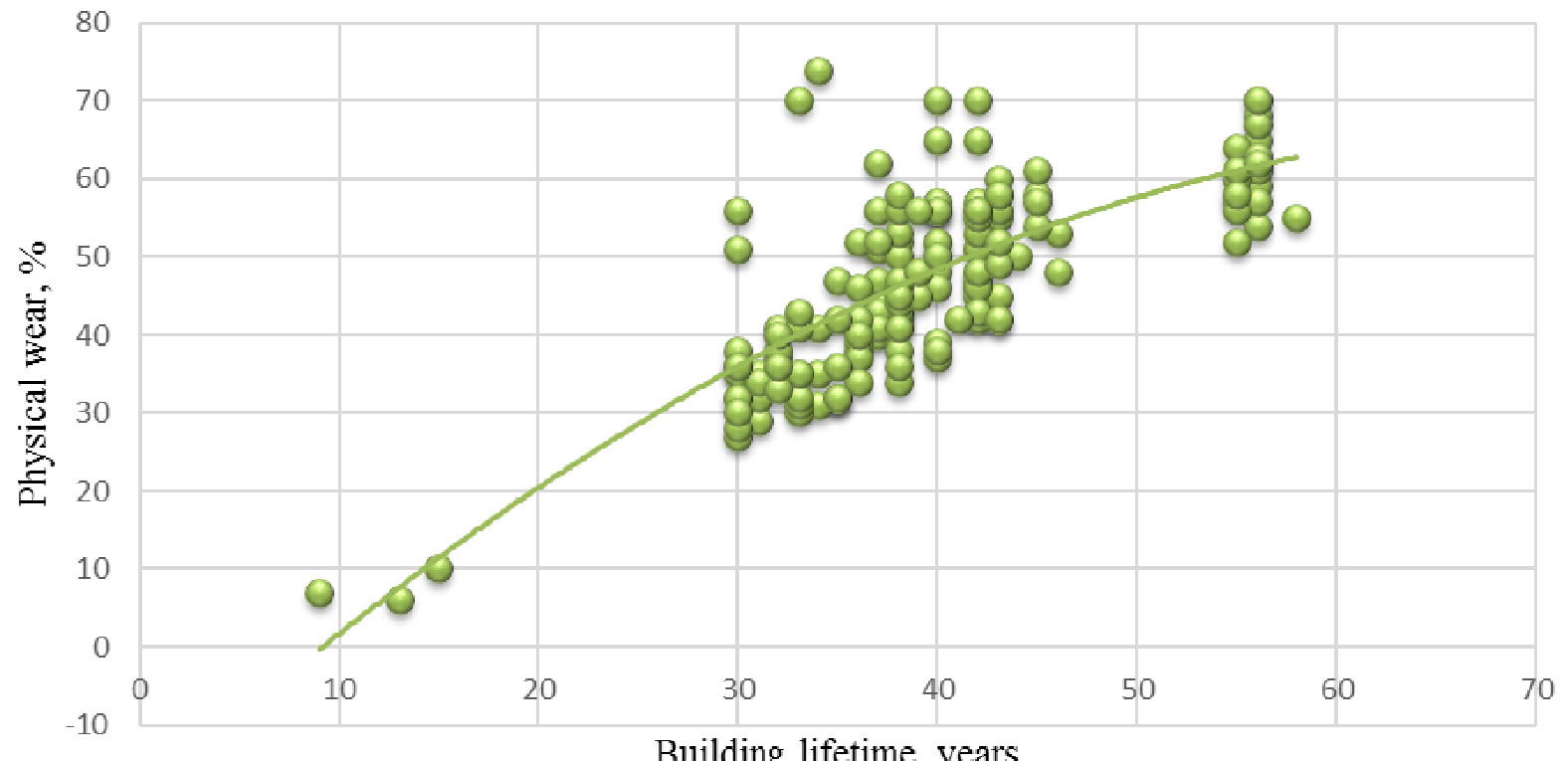

Building lifetime, years

Fig. 5. Relationship (based on polynomial regression) between physical depreciation depending and period of operation of fixed capital buildings at enterprises of the Russian Federation

As a result of the conducted study of the dependence of physical depreciation on the service life of AIC enterprise's buildings in the Russian Federation, the mathematical dependence of the physical depreciation of fixed capital buildings on the period of their operation was set in the form of a correlation-regression equation (1):

$$
y=-0.0159 x^{2}+2.353 x-20.301,
$$

where $y$-physical deterioration of the building;

$x$ - period of operation of the building.

The calculated correlation coefficient $r=0.5914$. The obtained value of the correlation coefficient shows the average dependence; therefore, the relationship is significant for the buildings in question on the balance of enterprises in the Russian Federation.

The authors view the structure of the process of monitoring the technical condition of buildings as elements of fixed assets as a set of information gathering and decision-making operations (Figure 6).

\section{Information system}

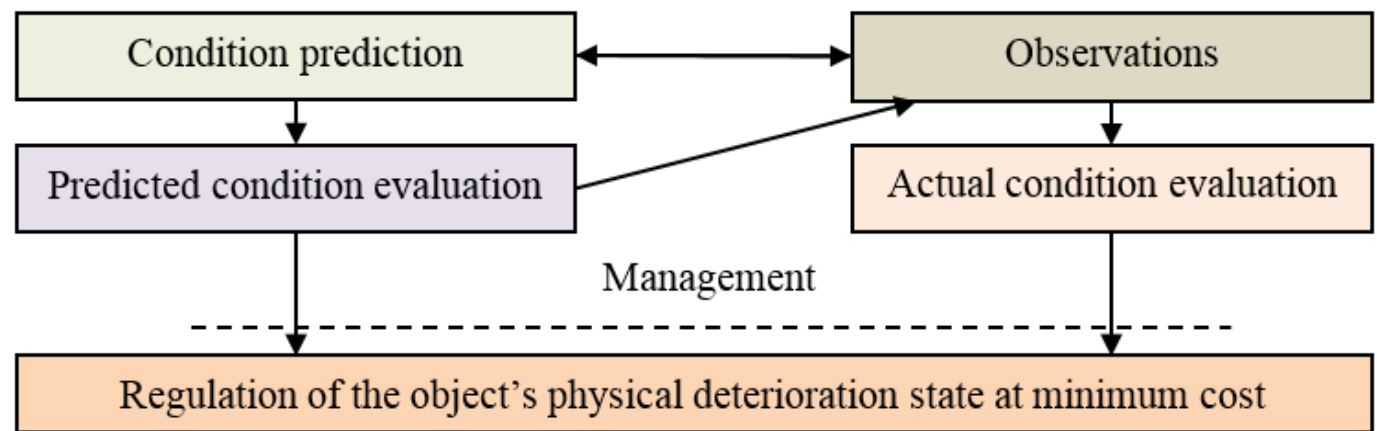

Fig. 6. Structure of AIC enterprise's buildings technical condition monitoring

\section{Results and discussion}

The authors determined that the reproduction of fixed assets in the form of repair and reconstruction of the enterprise's buildings is carried out through the stages of formation, 
capitalization and use of a depreciation fund. At the same time, at the first stage, the enterprise carries out the transfer of fixed assets to finished products, at the second stage, in the course of product sales, the transferred part of the cost of finished products forms a depreciation fund, and the third stage is characterized by the transfer of capital investments to the depreciation funds [26].

The study conducted by the authors allows to solve the problem of applying modern technical documentation for rationing the service life of buildings in order to optimize the use of depreciation estimates for the reproduction of fixed assets considering the full design life [27] and determine the recommended minimum service life of building elements presented in Table 1.

Table 1

Recommended minimum service life of building components (DLC), years

\begin{tabular}{|c|c|c|c|c|c|}
\hline $\begin{array}{c}\text { Group } \boldsymbol{j} \\
\text { project } \\
\text { life }\end{array}$ & $\begin{array}{c}\text { Full design } \\
\text { life of the } \\
\text { building }\end{array}$ & $\begin{array}{c}\text { Unavailable or } \\
\text { main building } \\
\text { elements }\end{array}$ & $\begin{array}{c}\text { Items which } \\
\text { replacement is } \\
\text { technically difficult } \\
\text { or costly }\end{array}$ & $\begin{array}{c}\text { Items to } \\
\text { be mass } \\
\text { replaced }\end{array}$ & $\begin{array}{c}\text { Items and parts } \\
\text { that are replaced } \\
\text { during } \\
\text { maintenance }\end{array}$ \\
\hline 1 & Not limited & Not limited & 100 & 40 & 25 \\
\hline 2 & 150 & 150 & 100 & 40 & 25 \\
\hline 3 & 100 & 100 & 100 & 40 & 25 \\
\hline 4 & 60 & 60 & 60 & 40 & 25 \\
\hline 5 & 25 & 25 & 25 & 25 & 25 \\
\hline 6 & 15 & 15 & 15 & 15 & 15 \\
\hline 7 & 10 & 10 & 10 & 10 & 10 \\
\hline \multirow{2}{*}{ Notes } & $\begin{array}{l}1 . \\
2 .\end{array}$ & $\begin{array}{l}\text { Easily replaceable items may have a service life of 3 to 6 years. } \\
\text { Thimits the design capabilities }\end{array}$ \\
\end{tabular}

The design of significant volumes of fixed assets of enterprises that are in operation at the present stage was carried out based on the regulatory technical documentation in force at the time of commissioning, which has undergone numerous changes now. This provision significantly complicated the rationale for the distribution of capital investments for the reproduction of fixed assets, which required scientific study, since one of the main starting points for planning the restoration of buildings as elements of fixed assets in an enterprise is the standard term of service for buildings.

The results of investigations provided by the authors [24, 25]show that in general development of physical depreciation of buildings as a type of fixed assets is non-linear in time and proceeds in 3 stages, in which the value of the development of physical wear quickly increases after entering the facility into operation and then stabilizes for a considerable period of time, called the period of normal operation, with the subsequent deterioration of the technical condition of the building (Figure 7).

The values of funds allocated to each of the categories of buildings are determined by the calculation of the corresponding distribution coefficients. The objective function in general will be (2):

$$
K_{1} \cdot S_{1}+K_{2} \cdot S_{2}+\ldots+K_{n} \cdot S_{n}=S_{\text {all }},
$$

or

$$
\sum_{i=1}^{n}\left(K_{n} \cdot S_{n}\right)=S_{\text {all }},
$$

where $i=1,2,3 \ldots n$ - number of building categories in accordance with the accepted classification of fixed assets in the enterprise;

$S_{i}$ - number of capital investments for each $i^{\text {th }}$ category of buildings in accordance with the accepted classification of fixed assets in the enterprise;

$S_{\text {all }}$ - total number of capital investments allocated from the depreciation fund of the enterprise to eliminate physical deterioration of buildings;

$K_{i}$ - distribution coefficient of capital investments determined empirically by each $i^{\text {th }}$ category of buildings of the enterprise. 


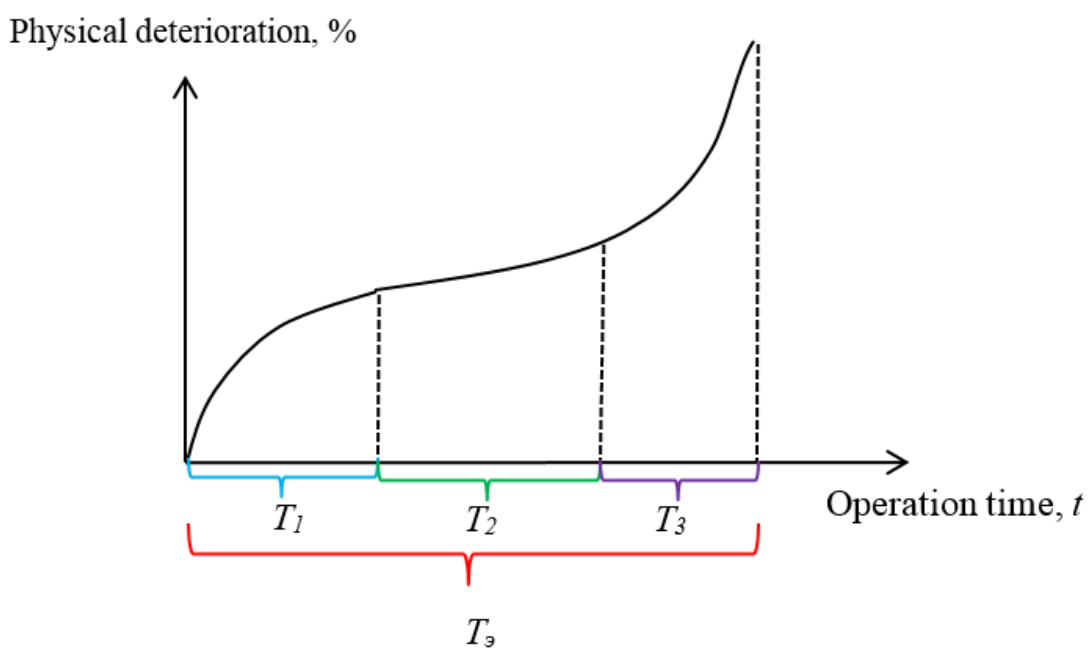

Fig. 7. Development of physical deterioration in operation of buildings: $T_{1}$ - period of running-in;

$T_{2}$ - period of stabilization; $T_{3}$ - period of increase in the rate of development of physical wear; $T_{a}-$ total life of the building

The decision-making process on the allocation of capital investments for the reproduction of fixed assets is carried out in accordance with the algorithm presented in Figure 8.

At the $1^{\text {st }}$ stage the company management in order to reasonably distribute capital investments from the depreciation fund to eliminate physical deterioration of buildings is organized on the terms of contracts for building inspection with substantiation of the technical condition group. The building's survey results serve as a basis for project documentation development and determining the type of restoration work (current repair, major repairs or reconstruction).

At the $2^{\text {nd }}$ stage the enterprise management determines the number of categories of buildings that require an appropriate type of restoration work. Classification of buildings by category as elements of fixed assets can be performed depending on the attitudes of the officials who make decisions.

At the $3^{\text {rd }}$ stage the enterprise management determines the capital investments amount sent from the depreciation fund to the corresponding type of restoration work. This decision is made based on the analysis of the technical condition examination results and the corresponding estimate documentation for each building from the fixed assets. In case of absence of the necessary amount in the depreciation fund, it is advisable to forward part of the profits to eliminate buildings physical deterioration.

$$
\frac{a_{i}}{a_{i+1}}+\frac{a_{i}}{a_{i+2}}+\frac{a_{i}}{a_{i+3}}+\ldots+\frac{a_{i}}{a_{i+p}}=1,
$$

where $a_{i}$-coefficient of the building category, which is the most significant and taken as the base;

$a_{i+p}-$ coefficient of subsequent category in the presence of $n$ categories of enterprise buildings.

At the $5^{\text {th }}$ stage the management analyses design documentation for the elimination of physical deterioration in order to classify the cost of carrying out restoration work by groups of design service life of buildings. In each group the arithmetic average value of the restoration work cost is determined depending on the group of design service life of buildings.

At the $4^{\text {th }}$ stage the management determines the most significant and accepted for the basic category of buildings from the composition of fixed assets that need to be carried out for restoration work. Next, pairwise comparison of the significance of the remaining categories of buildings from the composition of fixed assets is performed in such a way that condition (4) is fulfilled: 


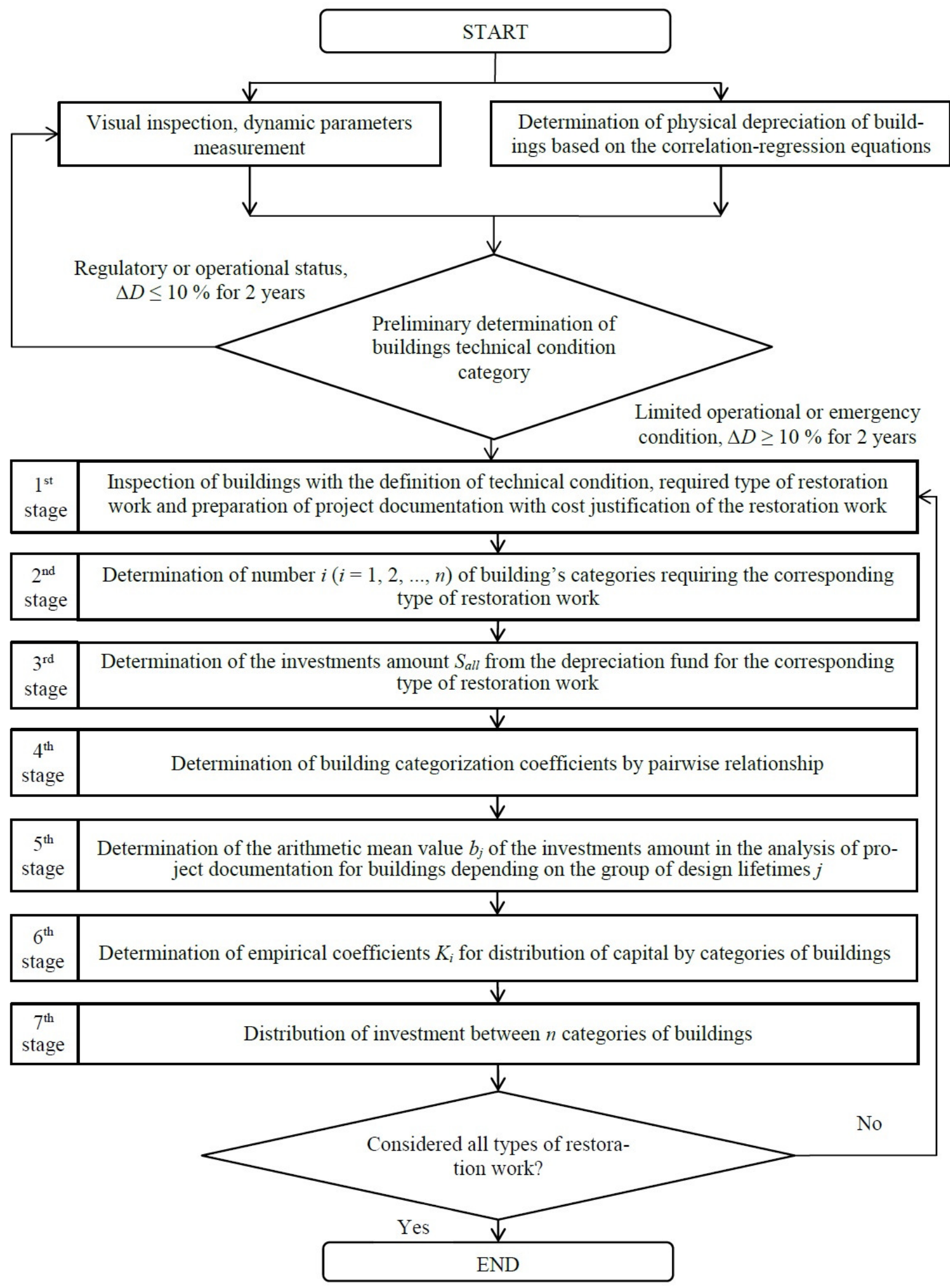

Fig. 8. Algorithm for deciding on planning of reproduction of fixed assets

At the $6^{\text {th }}$ stage the enterprise management calculates the empirical coefficients for the distribution of capital investments by building categories according to the formula (1), ranking by their significance according to agreed building Key Performance Indicators (KPIs) [20].In the case of assigning the category of buildings No. 1 as the most significant and accepted as the basic category, the empirical coefficient is assumed to be 1. The categories significance distribution is well 
represented in [11]. Then the empirical coefficients of the subsequent categories of buildings for formula (1) are determined by (5):

$$
\left(\frac{a_{i}}{a_{i+1}} / \frac{b_{j}}{b_{j+1}}\right)=K_{2}\left(\frac{a_{i}}{a_{i+2}} / \frac{b_{j}}{b_{j+2}}\right)=K_{3}\left(\frac{a_{i}}{a_{i+p}} / \frac{b_{j}}{b_{j+m}}\right)=K_{n},
$$

where $a_{i}$-coefficient of the building category, which is the most significant and taken as the base;

$a_{i+p}-$ coefficient of subsequent category in the presence of $n$ categories of enterprise buildings.

$b_{j}$ - arithmetic average value of restoration work cost for buildings of the $1^{\text {st }}$ project life group;

$b_{j+m}$ - arithmetic average value of restoration work cost for buildings of each subsequent group $m$ of the design life.

At the $7^{\text {th }}$ stage the enterprise management distributes the volume of capital investments among $n$ categories of buildings as follows. The value of the number of capital investments for category 1 of buildings in accordance with the accepted classification of fixed assets at the enterprise is taken as the only variable in formula (1) and expression (6) becomes fair:

$$
\left(K_{1}+K_{2}+K_{3}+\ldots+K_{n}\right) \cdot \mathrm{S}_{1}=S_{\text {all }} .
$$

After determining the number of capital investments for category 1 of buildings, the calculation of the number of capital investments for each subsequent category of buildings is performed as:

$$
\begin{aligned}
& K_{2} \cdot S_{1}=S_{2}, \\
& K_{3} \cdot S_{1}=S_{3}, \\
& K_{n} \cdot S_{1}=S_{n} .
\end{aligned}
$$

If there are buildings in the enterprise that need to carry out a different type of restoration work, distribution of capital investments for the corresponding type of restoration work is carried out similarly with the implementation of actions of the stage 2 (Fig. 8).

\section{Conclusions}

In the course of the study it was determined that the development of physical depreciation of buildings as elements of the company's fixed assets is non-linear in nature, and the existing methods for calculating depreciation deductions for the purpose of reproducing fixed assets do not allow to plan the complex implementation of restoration works for buildings of various purpose with elevated physical values of wear in an optimal way.

Based on the results of the study of methods for calculating depreciation and regulatory documents governing the respective service life of buildings, a technique was developed to optimize the planning of capital investments to eliminate the physical deterioration of AIC enterprise buildings as elements of fixed assets. The proposed functions and dependences in the methodic could be solved with accumulated calculation errors not exceeding 7-10\%, which allows the use of the proposed model for engineering calculations. The application of the developed methodology allows to increase the efficiency of management decision-making, which has an impact on the AIC enterprises effectiveness.

\section{References}

[1] Цыпин А.П., Попов В.В. Статистический анализ основных фондов России: наличие, состояние, эффективность использования (Tsipin A.P., Popov V.V. Statistical analysis of fixed 
assets of Russia: availability, status, efficiency of use). The azimuth of scientific research: economics and management, 2017, Vol. 6., No 3 (20), pp. 355-357. (In Russian).

[2] Сазонов В.Г., Разумова Ю.В. Повышение эффективности воспроизводства основных фондов - насущная задача модернизации национальной экономики (Sazonov V.G., Razumova Yu.V. Improving the efficiency of reproduction of fixed assets - an urgent task of modernizing the national economy). Bulletin of the Pacific State University of Economics, 2012, No 2, pp. 53-62. (In Russian).

[3] Россия в цифрах. Краткий статистический сборник (Russia in numbers. Short statistical compilation). Federal State Statistics Service, 2017. (In Russian).

[4] "ОК 013-2014 (СНС 2008). Общероссийский классификатор основных фондов" (ОК 0132014 (SNS 2008). All-Russian classifier of fixed assets) (adopted and put into effect by the Order of Rosstandart dated 12.12.2014 N 2018-st) (ed. 05.08.2018) (In Russian).

[5] Мартынов В.Ф., Кашина Е.В. Стоимость предприятия как критерий отбора проектов воспроизводства основных фондов (на примере легкой промышленности) (Martynov V.F., Kashina E.V. Enterprise value as a criterion for selecting projects for the reproduction of fixed assets (by the example of light industry). Problems of the modern economy, 2012, No 1, pp. 132135. (In Russian).

[6] Матиевич A.С. Исследование сущности и способов воспроизводства основных фондов (Matiyev A.S. Investigation of the essence and methods of reproduction of fixed assets). Bulletin of Siberian Science (Electronic Journal) URL: www.sjs.tpu.ru/journal/article/view/377. No 3 (4), 2012. (In Russian).

[7] Sharif S.A., Hammad A. Simulation-Based Multi-Objective Optimization of institutional building renovation considering energy consumption, Life-Cycle Cost and Life-Cycle Assessment. Journal of Building Engineering, Vol. 21, January 2019, pp. 429-445. https://doi.org/10.1016/j.jobe.2018.11.006

[8] Javid A.S., Aramoun F., Bararzadeh M., Avami A. Multi objective planning for sustainable retrofit of educational buildings. Journal of Building Engineering, Vol. 24, July 2019, 100759. https://doi.org/10.1016/j.jobe.2019.100759

[9] Ighravwe D.E., Oke S.A. A multi-criteria decision-making framework for selecting a suitable maintenance strategy for public buildings using sustainability criteria. Journal of Building Engineering, Vol. 24, July 2019, 100753. https://doi.org/10.1016/j.jobe.2019.100753

[10] Баскова A.P. Воспроизводство основных фондов в электроэнергетике России (Baskova A.R. Reproduction of fixed assets in the power industry of Russia). Actual problems of economics and law, No 1, 2011, pp. 43-45. (In Russian).

[11] Ali A.S., Azmi N.F., Baaki T.K. Cost performance of building refurbishment works: the case of Malaysia. International Journal of Building Pathology and Adaptation, Vol. 36, Issue 1, pp. 41-62. https://doi.org/10.1108/IJBPA-02-2017-0010

[12] Sundling R., Blomsterberg A., Landin A. Enabling energy-efficient renovation: the case of vertical extension to buildings. Construction Innovation, Vol. 19, Issue 1, pp. 2-14. https://doi.org/10.1108/CI-04-2018-0034

[13] Ларин С.Н. Критериальный подход к оценке эффективности воспроизводства жилищного фонда (Larin S.N. Criteria approach to evaluating the efficiency of reproduction of the housing fonds). Economic analysis: theory and practice, 2012, No 25 (280), pp. 33-43. (In Russian).

[14]Попова О.Н. Метод календарного планирования жилых зданий на основе их структурного анализа (Popova O.N. The scheduling method for residential buildings based on their structural analysis). Dissertation of the candidate of technical sciences, Moscow, SPbGASU, 2014, $171 \mathrm{p}$. (In Russian).

[15] Issa M.H., Attalla M., Rankin J.H., Christian A.J. Detailed Analysis of the Construction, Operating, Maintenance, and Rehabilitation Costs of Green Toronto Schools. Journal of Architectural Engineering, Vol. 19, Issue 1, March 2013. https://doi.org/10.1061/(ASCE)AE.1943-5568.0000093

[16] Silva A., de Brito J. Do we need a buildings' inspection, diagnosis and service life prediction software? Journal of Building Engineering, Vol. 22, March 2019, pp. 335-348. https://doi.org/10.1016/j.jobe.2018.12.019 
[17] Matarneh S.T., Danso-Amoako M., Al-Bizri S., Gaterell M., Matarneh R. Building information modeling for facilities management: A literature review and future research directions. Journal of Building Engineering, Vol. 24, July 2019, 100755. https://doi.org/10.1016/j.jobe.2019.100755

[18] Ogbeifun E., Mbohwa C., Pretorius J.-H.C. Developing an effective renovation plan: the influence of data collection tools. International Journal of Building Pathology and Adaptation, Vol. 36 Issue 1, pp. 63-76. https://doi.org/10.1108/IJBPA-09-2017-0035

[19]Roberts C. J., Pärn E.A., Edwards D.J., Aigbavboa C. Digitalising asset management: concomitant benefits and persistent challenges. International Journal of Building Pathology and Adaptation, Vol. 36, Issue 2, pp. 152-173. https://doi.org/10.1108/IJBPA-09-2017-0036

[20]Dejaco M.C., Re Cecconi F., Maltese S. Key Performance Indicators for Building Condition Assessment. Journal of Building Engineering, Vol. 9, January 2017, pp. 17-28. https://doi.org/10.1016/j.jobe.2016.11.004

[21] Jingmond M., Ågren R. Unravelling causes of defects in construction. Construction Innovation, Vol. 15, Issue 2, pp.198-218. https://doi.org/10.1108/CI-04-2014-0025

[22] Silva A., de Brito J., Gaspar P.L. A comparative multi-criteria decision analysis of service life prediction methodologies for rendered façades. Journal of Building Engineering, Vol. 20, November 2018, pp. 476-487. https://doi.org/10.1016/j.jobe.2018.08.009

[23]ГОСТ 31937-2011 от 27 декабря 2012 года «Здания и сооружения. Правила обследования и мониторинга технического состояния» (GOST 31937-2011 dated December 27, 2012 "Buildings and facilities. Rules of inspection and monitoring of the technical condition"). (In Russian).

[24]Магурин В.М., Азгальдов Г.Г., Белов О.Е., Бирюков А.Н. Квалиметрическая экспертиза строительных объектов (монография). (Magurin V.M., Azgaldov G.G., Belov O.E., Biryukov A.N. Qualimetric examination of construction objects (monograph)). Politechnika, SaintPetersburg, 2008, 527 p. (In Russian).

[25]Бирюков А.Н., Денисов В.Н., Бирюков Ю.А. Снос зданий и сооружений в современных условиях (монография). (Biryukov A.N., Denisov V.N., Biryukov Yu.A. Demolition of buildings and structures in modern conditions (monograph)). VA MTO, Saint-Petersburg, 2014, 256 p. ISBN978-5-9905907-2-4. (In Russian).

[26]Шонин А.Ю., Никоненко А.Н. К вопросу эффективной эксплуатации объектов недвижимости промышленного предприятия (Shonin A.Yu., Nikonenko A.N. On the issue of efficient operation of real estate industrial enterprises). 2011, No 2, pp. 2009-2014. (In Russian).

[27] ISO International Standards Organization. (2000). Buildings and constructed assets-Service Life Planning, part 1: General Principles, ISO 15686-1, ISO, Switzerland. 